\title{
HUBUNGAN SUPERVISI KEPALA SEKOLAH DAN MOTIVASI KERJA GURU DENGAN KINERJA GURU DI SEKOLAH MENENGAH ATAS WILAYAH BINAAN V KABUPATEN TANGERANG
}

\author{
${ }^{1}$ Megawati, ${ }^{2}$ Jarnawi Afgani Dahlan, \& ${ }^{1}$ Ambuy Sabur \\ ${ }^{1}$ Pascasarjana UNIS - Tangerang \\ ${ }^{2}$ Departemen Pendidikan Matematika FPMPA UPI \\ Email: megaazka5@gmail.com
}

\begin{abstract}
Abstrak
Tujuan dari penelitian ini adalah untuk mengetahui hubungan antara supervisi kepala sekolah dan motivasi kerja guru dengan kinerja guru di Sekolah Menengah Atas Wilayah Binaan V Kabupaten Tangerang. Populasi di dalam penelitian ini sebanyak 156 orang guru, dan yang di jadikan sampel sebanyak 112 guru yang tersebar dari beberapa Sekolah Menengah Atas di Wilayah Binaan V yaitu SMAN 5 Kabupaten Tangerang, SMAN 12 Kabupaten Tangerang, SMA HIRO, SMA PGRI dan SMA BABUSSALAM. Penelitian ini merupakan penelitian kuantitatif. Pengambilan data di dalam penleitian ini menggunakan angket dengan skala likert. Sedangkan analisis datanya menggunakan persamaan regresi linier sederhana dan regresi berganda. Untuk mengetahui kebermaknaan di dalam persamaan regresi di gunakan uji t dan uji F. hasil penelitian ini menunjukkan bahwa hubungan supervisi kepala sekolah mempunyai hubungan yang positif dan signifikan dengan kinerja guru di Sekolah Menengah Atas Wilayah Binaan V Kabupaten Tangerang. Motivasi kerja guru mempunyai gubungan yang positif dan signifikan dengan kinerja guru di Sekolah Menengah Atas Wilayah Binaan V Kabupaten Tangerang. Supervisi kepala sekolah dan motivasi kerja guru secara bersama - sama mempunyai hubungan yang positif dan signifikan dengan kinerja guru di Sekolah Menengah Atas Wilayah Binaan V Kabupaten Tangerang, sehingga dapat di simpulkan bahwa supervisi kepala sekolah dan motivasi kerja guru dengan kinerja guru memiliki hubungan yang positif dan signifikan.
\end{abstract}

Kata Kunci: Motivasi Kerja, Kinerja, Guru, Kepala Sekolah

\begin{abstract}
The purpose of this study was to determine the relationship between the principal supervisor and motivation of teachers working with teacher performance at Senior High School on educated In the Region V Tangerang District. The population, or as many as 156 teachers and as many as samples 112 teachers, spread over 5 in the school, there are SMAN 5 Kabupaten Tangerang, SMAN 12 Kabupaten Tangerang, SMA HIRO, SMA PGRI and SMA BABUSSALAM. This research is a quantitative research. data collecting in this study was using a questionnaire with Likert scale. While the analysis of the data was using a simple linier regression equation, the $t$ and $F$ test were use. The result showed that the principal supervisor had related positive and significant with the performance of Senior High School on educated In the Region V Tangerang. Motivation of teachers working had related positive and significant with the performance of Senior High School on Educated in the Region V Tangerang. The principal supervisor and
\end{abstract}


motivation of teachers working together had related positive and significant with the performance of Senior High School on Educated in the Region V Tangerang.

Keywords: Perpormace, Motivation, Teacher, Head Master.

\section{A. Pendahuluan}

Negara Indonesia pada saat ini memiliki beberapa masalah, salah satunya didalam dunia pendidikan. Pendidikan merupakan suatu hal yang sangat penting untuk membangun suatu negara yang maju. Pendidikan juga merupakan suatu wahana yang dapat mengembangkan dan meningkatkan kualitas sumber daya manusia. Kualitas sumber daya manusia masih terlihat rendah di Negara Indonesia, salah satunya didunia pendidikan. Dan untuk bisa meningkatkan dan mengembangkan sumber daya manusia perlu adanya suatu tindakan dari suatu pemerintah.

Sumber daya manusia sangat penting dalam mengembangkan kemajuan suatu Negara. Seperti didalam suatu pendidikan disekolah, masih terdapat banyaknya sumber daya manusia yang masih rendah dalam meningkatkan atau mengembangkan potensi kerja untuk memanjukan suatu bangsa yang maju.

Purwanto (2012) yang mengemukakan bahwa "Supervisi adalah suatu aktivitas pembinaan yang direncanakan untuk membantu para guru dan pegawai sekolah lainnya dalam melakukan pekerjaan mereka secara efektif'. Apabila supervisi dilaksanakan dengan baik, tentu akan memeperbaiki kinerja guru dalam kegiatan pembelajaran, sebagai seorang supervisor kepala sekolah harus memiliki kompetensi supervisi dalam melakukan tugasnya sebagai kepala sekolah. Kegiatan supervisi yang dilakukan harus sesuai dengan kebutuhan guru. Kegiatan supervisi diawali dengan perencanaan, pelaksanaan dan menindaklanjuti kegiata supervisi.

Dengan adanya pembinaan oleh kepala sekolah diharapkan dapat memberikan dampak yang positif terhadap terbentuknya sikap profesional guru. Sikap profesional guru merupakan hal yang penting dalam memelihara dan meningkatkan profesionalitas guru. Karena selalu berpengaruh terhadap prilaku dan aktivitas keseharian guru.

Seorang guru harus memiliki profesionalitas yang tinggi agar terciptanya kinerja yang baik untuk menjalankan tugasnya secara optimal. Seperti yang dikutip oleh Sedarmayanti (2011) menyatakan bahwa "kinerja guru merupakan kemampuan dan sebuah keberhasilan didalam menjalankan tugasnya dan tanggung jawabnya dalam mencapai tujuan". Kinerja guru dipengaruhi beberapa faktor seperti yang dikutip oleh A. Anwar Prabu Mangkunegara (2011:67) yang mengemukakan bahwa "Faktor - faktor yang mempengaruhi kinerja yaitu faktor motivasi dan faktor kemampuan”.

Rendahnya atau menurunnya kinerja guru dipengaruhi dari beberapa faktor, baik faktor intern maupun ekstern, seperti yang dikutif didalam Mulyasa (2007) mengungkapkan bahwa,'Faktor internal terdiri dari; (1) dorongan untuk bekerja, (2) tanggung jawab 
dalam tugas, (3) minat terhadap tugas, sedangkan faktor eksternal terdiri dari; (1) mendapatkan perghargaan atas tugas, (2) mengembangkan prestasi, (3) mendapatkan perhatian khusus dari atasan, (4) hubungan interpersonal terhadap sesama pekerja, (5) adanya pelatihan". Untuk itulah dalam penelitian akan dikaji tentang hubungan antara supervise kepala sekolah dengan kinerja guru.

\section{Kerangka Teoritis}

\section{Kinerja Guru}

Pendidikan suatu wahana yang dapat mengembangkan dan emningkatkan kualitas sumber daya manusia. Kualitas sumber daya manusia masih terlihat rendah di Negara Indonesia, salah satunya didunia pendidikan, dan untuk bisa meningkatkan dan mengembangkan sumber daya manusia perlu adanya suatu tindakan dari suatu pemerintah.

Sekolah adalah suatu lembaga pendidikan yang dimana menjadi tempat untuk menimba ilmu, dan mengembangkan potensi bagi para peserta didik. selain itu sekolah juga adalah tempat untuk melaksanakan kegiatan belajar mengajar antara siswa dengan guru, guru dengan staff, pegawai dengan kepala sekolah dan pegawai lainnya. Tujuan kegiatan belajar mengajar akan terlaksana dengan baik dan lancar apabila terdapat komponen - komponen yang memadai, misalnya; sarana prasarana, adanya tenaga pengajar yang qualified, terdapat struktur organisasi yang terstruktur, dan adanya kepala sekolah.Sekolah yang berkualitas harus memiliki visi dan misi yang dapat membangun infrastruktur yang bagus.

Kinerja guru menurut Ilyas yang dikutip oleh Samsudin (2006:9) mengemukakan bahwa "Kinerja sebagai tahapan dalam pelaksanaan sebuah tugas yang ingin dicapai oleh seseorang dengan menggunakan kemampuan ynag dimiliki untuk mencapai suatu tujuan sebuah organisasi".

Kinerja guru dipengaruhi oleh beberapa faktor seperti yang dikutip oleh Wibowo (2007) yang mengemukakan bahwa "Kinerja guru dipengaruhi oleh pengetahuan, sikap, kemmapuan, gaya kerja, kepribadian, minat, dasar-dasar nilai, kepercayaan dan gaya kepemimpinan". Sesuai dengan yang dikutip oleh Timpe (1993) yang menjelaskan faktor-faktor yang mempengaruhi kinerja guru diantaranya "Linkungan kerja, motivasi kerja, gaya kepemimpinan, prilaku, sikap dan hubungan dengan rekan kerja".

Berkenaan dengan ini, tugas pokok guru dalam kegiatan pembelajaran dapat diketahui dalam Permendikbud Standar Proses Pembelajaran No. 41 Tahun 2007 bahwa proses kegiatan pembelajaran meliputi: (1) perencanaan kegiatan pembelajaran; (2) pelaksanaan kegiatan pembelajaran; (3) penilaian hasil kegiatan pembelajaran.

Berdasarkan uraian di atas dapat disimpulkan kinerja guru yaitu suatu persiapan, pelaksanaan maupun pencapaian dalam melaksanakan kegiatan pembelajaran yang bertujuan untuk mencapai kegiatan belajar mengajar dikelas yang baik dan kreatif. Kinerja guru sangat 
pentinguntuk diperhatikan dan juga untuk dievaluasi karena guru mengemban tugas yang profesional, artinya tugas-tugas guru hanya dapat dilakukan dengan sebuah kompetensi khusus yang diperoleh melalui program-program pendidikan. Seorang guru juga harus memiliki sebuah rasa tanggung jawab yang sangat besar di antaranya: 1) guru sebagai tenaga pengajar, 2) guru sebagai pembimbing, dan 3) guru sebagai administrator kelas.

\section{Supervisi Kepala Sekolah}

Hakikat supervisi di dalam dunia pendidikan adalah suatu proses pembimbingan dari pihak berkompenten termasuk kepala sekolah kepada guru-guru dan pegawai lainnya yang langsung menangani belajar peserta didik, untuk memperbaiki suasana kegiatan belajar mengaraj agar peserta didik dapat belajar secara efektif dan prestasi belajar menjadi meningkat. Sebagaimana yang dikutip oleh Purwanto (2012) yang mengemukakan bahwa "Supervisi adalah suatu aktivitas pembinaan yang direncanakan untuk membantu para guru dan pegawai sekolah lainnya dalam melakukan pekerjaan mereka secara efektif".

Seseorang yang dapat dikatakan seorang supervisor disekolah adalah seorang kepala sekolah, sebagaimana yang dikutip dalam Mulyasa (2007) yang mengatakan bahwa "kepala sekolah harus dapat menjalankan tugas dan perannya yaitu sebagai seorang supervisor". Seperti yang dijelaskan di dalam Permendiknas Nomor 13 Tahun 2007 menjelaskan bahwa "Seorang kepala sekolah harus mampu dalam menguasai dibidang Kompetensi Kepala Sekolah yaitu salah satu nya adalah supervisi”.

Kepala sekolah slain sebagai seorang pimpinan juga seorang seorang supervisor, yang dimana bertugas dalam memberikan pembinaan atau pengawasan terhadap guru, untuk dapat meningkatkan kualitas kinerjanya. Secara manajerial kegiatan supervisi mencakup dari kegiatan dalam merencanakan kegiatan supervisi, melaksanakan kegiatan supervisi, dan mengevaluasi tindak lanjut. Seperti yang dijelaskan di dalam Peraturan Menteri Nomor 13 Tahun 2007, dijelaskan bahwa seorang kepala sekolah harus mempunyai kompetensi di dalam kegiatan supervisi, diantaranya adalah:

1. Menyusun perencanaan dalam kegiatan program supervisi akademik untuk meningkatkan profesionalisme guru.

2. Melaksanakan kegiatan program supervisi akademik terhadap para guru dengan melalui pendekatan dan beberapa teknik supervisi akademik yang tepat.

3. Menindaklanjuti hasil kegiatan supervisi akademik yang telah dilakukan oleh pihak sekolah terhadap para guru untuk meningkatkan profeisonalisme guru.

Berdasarkan uraian di atas dapat disimpulkan bahwa supervisi kepala sekolah adalah suatu kegiatan yang dilakukan oleh kepala skeolah dalam bentuk pembinaan terhadap guru dengan tujuan untuk meningkatkan 
dan mengembangkan kinerjanya. Adapun kompetensi yang harus dimiliki seorang supervisor yaitu: perencanaan, pelaksanaan dan menindaklanjuti. Seperti yang dikutip oleh Rivai (1981) yang mengemukakan bahwa "Karakteristik di dalam perencanaan supervisi terdiri dari; 1) supervisi tidak ada rencana yang standar, 2) perencanaan supervisi memerlukan kreativitas, 3) komprehensif, 4) kooperatif, dan 5) fleksibel.

\section{Motivasi Kerja Guru}

Setiap manusia memiliki kebutuhan masing-masing, sebuah keinginan untuk dapat memenuhi kebutuhannya yaitu mendorong manusia untuk dapat melakukan berbagai upaya dalam menggapainya atau mencapainya. Motivasi memiliki hubungan yang sangat erat di dalam kebutuhan manusia. seperti yang dikutip oleh Wina Sanjaya (2013) yang mengemukakan bahwa "Seseorang akan terdorong dan bertindak untuk memenuhi kebutuhannya".

Upaya manusia dalam memenuhi itu semua dipengaruhi oleh beberapa faktor, sebagaimana yang dikutip oleh Maslow (2012) yang mengemukakan bahwa "Motivasi manusia dipengaruhi oleh lima kebutuhan dasar, yaitu; 1) kebutuhan psikologis, kebutuhan rasa aman dan perlindungan, kebutuhan social, kebutuhan akan penghargaan dan kebutuhan akan aktualisasi diri”.

Motivasi kerja seseorang dapat diukur dengan berbagai pandangan, seperti yang dikutip oleh Riduwan (2010) menjelaskan bahwa "Motivasi kerja guru dapat diukur dalam dua

Vol 2, No 1 (2020) pandangan, yaitu motivasi kerja secara eksternal dan motivasi kerja internal". adapun motivasi kerja eksternal diantaranya adalah hubungan kerja pribadi, gaji (honorium), kegiatan supervisi kepala sekolah, kondisi suasana tempat kerja. Sedangkan motivasi kerja guru internal yaitu; dorongan seseorang untuk bekerja lebih giat, meningkatkan kinerja yang lebih optimal, sebuah pengakuan dari atasan, minat dalam melaksanakan tugas.

Berdasarkan uraian di atas dapat disimpulkan bahwa motivasi kerja guru adalah suatu dorongan atau keinginan seseornag dalam menggapai atau mencapai tujuan yang diinginkan.

\section{B. Metode Penelitian}

Penelitian ini menggunakan metode penelitian kuantiatif dengan teknik korelasional yang mengkaji hubungan antara tiga variabel peneliian; 1) supervisi kepala sekolah, 2) motivasi kerja guru, dan 3) kinerja guru. Adapun variabel bebas teridri dari supervisi kepala sekolah dan motivasi kerja guru sedangkan variabel terikat yaitu kinerja guru. Adapun design penelitian dapat dilihat sebagai berikut:

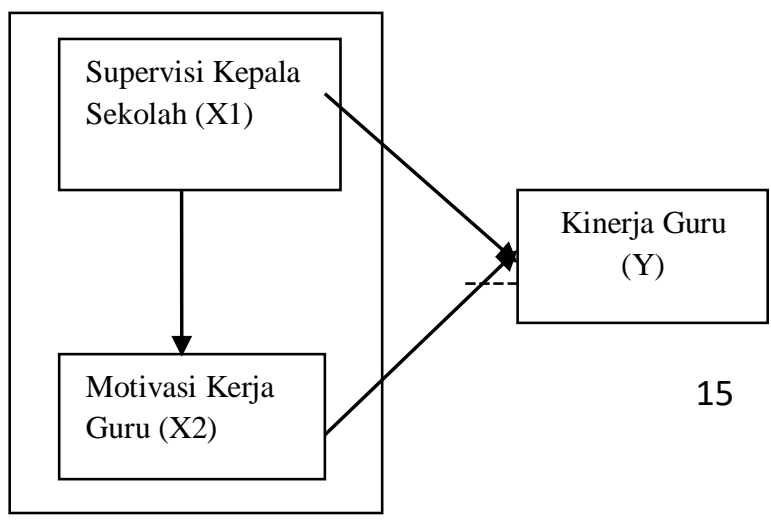




\section{Gambar 1. Hubungan antar Variabel}

Teknik pengambilan sampel menggunakan rumus slovin yang diperoleh ukuran sampel sebanyak 112 responden yang diambil dari guru di sekolah menengah atas (SMA) secara acak yang berada di Wilayah Binaan V Kabupaten Tangerang. Penelitian ini dilakukan dengan cara pengamatan secara langsung pada objek penelitian yang dituju. untuk menganalisis data menggunakan uji statistic korelasi dan regresi. Analisis ini adalah analisis tentang hubungan antara satu variabel terikat dengan dua variabel bebas. sebelum melakukan uji korleasi dan regresi, peneliti melakukan uji prasyarat yaitu uji normalitas, uji linieritas.

\section{Hasil Penelitian}

Penelitian ini untuk mencari hubungan antara supervisi kepala sekolah dan motivasi kerja guru dengan kinerja guru di Sekolah Menengah Atas Wilayah Binaan V Kabupaten Tangerang. Berdasarkan hasil hasil deskripsi data variabel kinerja guru di Sekolah Menengah Atas Wilayah Binaan V Kabupaten Tangerang adalah sebesar 84, 07\%, dengan kata lain masih 15, 93\% yang di pengaruhi oleh variabel lainnya.

Hasil deskripsi data variabel supervisi kepala sekolah di Sekolah Menengah Atas Wilayah Binaan V Kabupaten Tangerang di peroleh sebesar 85, 92\% dengan kata lain $14,08 \%$ yang di pengaruhi variabel lain. Sedangakan deskripsi data dari variabel motivasi kerja guru di Sekolah Menengah Atas Wilayah Binaan V Kabupaten Tangerang diperoleh sebesar 85,96\% dengan kata lain $14,04 \%$ di pengaruhi variabel lainnya.

Dengan demikian hasil perolehan ini menunjukkan bahwa sebagian guru di Sekolah Mennegah Atas Wilayah Binaan V Kabupaten Tangerang mempunyai kinerja dengan persentase yang sangat tinggi. Dalam penelitian ini di ungkapkan hubungan supervisi kepala sekolah dan motivasi kerja guru secara bersama-sama dengan kinerja guru

Berdasarkan hasil analisis hipotesis data pertama yang diperoleh mengenai hubungan supervisi kepala sekolah (X1) dengan kinerja guru (Y) diperoleh nilai korelasi sebesar 112 responden penelitian dapat diperoleh 0,302 pada sig (2-tailed) $=0,000$. Hasil penelitian ini menunjukkan bahwa terdapat hubungan positif yang signifikan antara supervisi kepala sekolah dengan kinerja guru di Sekolah Menengah Atas Wilayah Binaan V Kabupaten Tangerang. Hasil analisis korelasi juga menunjukkan adanya hubungan yang kuat antara motivasi kerja guru dengan kinerja guru sebesar 0,552 pada sig. (2-tailed) $=0,000$ dengan nilai signifikan lebih kecil dari 0,05 (a) maka dapat disimpulkan bahwa terdapat hubungan positif yang signifikan antara motivasi kerja guru dengan kinerja guru.

Selanjutnya hasil uji regresi linier dapat disimpulkan dengan seberapa 
besar hubungan supervisi kepala sekolah dan motivasi kerja guru dengan kinerja guru. Dari hasil perolehan pengujian koefisien korelasi (R ) dengan nilai sebesar 0,558 dan ini berarti bahwa supervisi kepala sekolah dan motivasi kerja guru dapat mempengaruhi kinerja guru sebesar $55,8 \%$.

Adapun hasil analisis di dalam penelitian ini menunjukkan bahwa:

1. Adanya hubungan positif yang kuat antara supervisi kepala sekolah dengan kinerja guru di Sekolah Menengah Atas Wilayah Binaan V Kabupaten Tangerang.

2. Adanya hubungan positif yang kuat antara motivasi kerja guru dengan kinerja guru di Sekolah Menengah Atas Wilayah Binaan V Kabupaten Tangerang.

Adanya hubungan positif yang kuat antara supervisi kepala sekolah dan motivasi kerja guru dengan kinerja guru di Sekolah Menengah Atas Wilayah Binaan V Kabupaten Tangerang. Hal ini sejalan dengan hasil penelitian yang dilakukan sebelumnya oleh Uli Uslihatul Auliya (2012) yang menyatakan bahwa terdapat pengaruh yang signifikan antara supervisi kepala sekolah dan motivasi kerja guru terhadap kinerja guru. Sebagaimana diketahui bahwa motivasi merupakan suatu hal yang sangat penting di dalam diri seorang guru. Motivasi menjadi satu kekuatan bagi seseorang dalam melaksanakan atau menjakankan kerja.

Adanya hubungan positif yang kuat antara supervisi kepala sekolah dengan kinerja guru yang dapat disimpulkan dalam penelitian ini dan mendukung hasil penelitian yang telah dilakukan sebelumnya oleh Edi Rismawan (2005) yang membuktikan bahwa terdapat pengaruh positi antara supervisi kepala sekolah dengan kinerja guru. Sebagaimana adanya hubungan positif yang kuat antara motivasi kerja guru dengan kinerja guru sejalan dengan penelitian sebelumnya yang dilakukan oleh Eri Agusti (2015) yang membuktikan bahwa adanya pengaruh positif antara motivasi kerja guru dengan kinerja guru.

\section{Kesimpulan}

Kesimpulan dari hasil penelitian ini sebagai berikut:

1. Terdapat hubungan positif yang siginifikan supervisi kepala sekolah dan motivasi kerja guru dengna kinerja guru di Sekolah Menengah Atas Wilayah Binaan V Kabupaten Tangerang. Artinya supervisi kepala sekolah dan motivasi kerja guru mempengaruhi kinerja guru di Sekolah Menengah Atas Wilayah Binaan V Kabupaten Tangerang.

2. Terdapat hubungan positif yang signifikan supervisi kepala sekolah dengan kinerja guru di Sekolah Menengah Atas Wilayah Binaan V Kabupaten Tangerang. Artinya untuk dapat meningkatkan kinerja guru harus di pastikan kepala sekolah melakukan supervisi dengan baik dan benar, sebab kinerja guru sangat dipengaruhi oleh supervisi yang dilakukan oleh kepala sekolah.

3. Terdapat hubungan positif yang signifikan motivasi kerja guru dengan kinerja guru di Sekolah 
Menengah Atas Wilayah Binaan

V Kabupaten Tangerang. Artinya untuk meningkatkan kinerja guru harus dipastikan bahwa guru tersebut memiliki motivasi kerja, karena kinerja sangat ditentukan oleh motivasi kerja sebagai guru.

\section{Daftar Pustaka}

Adeyemi, T.O. 2010. "Principal's Leadership Styles And Teachers' Job Performance In Senior Secondary School In Ondo State Nigeria". Journal Of Education Andminitration And Policy Studies. Volume 2 No. 6. Page $83-91$.

Astuti, S. 2017. "Supervisi Akademik Untuk Meningkatkan Kompetensi Guru Di SD Laboratorium UKSW". Jurnal Manajemen Pendidikan, Volume 7 No. 1. Hal $49-59$.

Auliya, U, U. 2012. "Pengaruh Supervisi Kepala Sekolah Dan Motivasi Kerja Guru Terhadap Kinerja Guru”. Jurnal Analisis Pendidikan Ekonomi. Volume 1 No. 2 Hal 9 - 13.

Auliya, U, U. 2012. "Pengaruh Supervisi Kepala Sekolah Dan Motivasi Kerja Guru Terhadap Kinerja Guru". Tesis. Semarang: Sekolah Pascasarjana UNS.

Cholil, M. 2014. "Pengaruh Kepemimpinan Kepala Sekolah Dan Motivasi Kerja Terhadap Kinerja Guru di SMP Muhamadiyah Ngawi”. Jurnal Ilmiah STKIPPGRI Ngawi. Volume 13 No. 1 Hal $92-101$.

Gusman, E, H. 2014. "Hubungan Gaya Kepemimpinan Kepala Sekolah Dengan Kinerja Guru di SMP N Kecamatan Palembayan Kabupaten Agam". Jurnal Administrasi Pendidikan. Volume 2 No. 1 Hal 293 - 831.

Hasibuan, M, SP. 2000. Organisasi \& Motivasi. Jakarta: Bumi Aksara.

Ilyas, I, M. 2010. “Kinerja Dan Kompetensi Guru Dalam Pembelajaran”. Jurnal Lentera Pendidikan, Volume 13 No. 1. Hal $44-63$.

Jasmani, A. 2013. Supervisi Pendidikan: Terobosan Baru dalam Kinerja Peningkatan Kerja Pengawas Sekolah dan Guru. Yogyakarta: Ar - Ruzz Media.

Jerry, H, M. 2011. Supervise dan Peningkatan Mutu Pendidikan. Bandung:Alfabeta.

Jihad, A.2019. "Hubungan Motivasi Kerja dan Supervisi kepala Sekolah dengan Kinerja Guru SMP NEGERI di Kecamatan Babahrut Aceh Barat Daya". Jurnal Administrasi Pendidikan, Volume 7 No. 1 Hal 7 - 12.

Karweti, E. 2010. "Pengaruh Kemapuan Manajerial Kepala Sekolah dan Faktor Yang Mempengaruhi Motivasi kerja Terhadap Kinerja Guru SLB Di Kabupaten Subang”. Jurnal Penelitian Pendidikan, Volume 11 No. 2. Hal $80-81$.

Mangkunegara, A, P. 2011. Evaluasi Kinerja SDM. Bandung: Aditama. 
Mulyadi, M. 2011. Penelitian Kuantitatif dan Kualitatif Serta Pemikiran Dasar Menggabungkannya". Jurnal Studi Komunikasi dan Media, Volume 15 No.1. Hal 131.

Mulyasa, E. 2007. Standar Kompetensi dan Sertifikasi Guru. Bandung: Citra Umbara.

Nadzir, M. 2013. "Perencanaan Pembelajaran Berbasis Karakter". Jurnal Pendidikan Agama Islam, Volume 02 No. 2. Hal 339 - 352

Nurhayati, S. 2013. "Hubungan Kinerja Supervisor Dengan Tingkat Kompetensi Guru Sekolah Dasar di Kota Malang. Jurnal Kebijakan dan Pengembangan Pendidikan. Volume 1 No. 2 Hal 194 - 202.

Piter,S.2011. "Hubungan Supervisi Kepala Sekolah dan Motivasi Kerja Dengan Kinerja guru di SMP Se - kecamatan Medang Deras Kabupaten Batubara". Jurnal Administrasi Pendidikan, Volume 1 No. 2 Hal 42 - 65.

Purwanto, N. 2012. Administrasi dan Supervisi Pendidikan. Bandung: Remaja Rosdakarya. Range, G, B. 2013. "How Teachers' Perceive Principal Supervision And Evaluation In Eight Elementary School”. International Journal Of Research In Education. Volume 2 No. 6 Page 66 - 78.

Riduwan. 2010. Belajar Mudah Penelitian Untuk Guru - Karyawan Dan Peneliti Pemula.Bandung: Alfabeta.

Rifaldi, A, M. 2014. "Pengaruh Supervisi Kepala Sekolah Dan Motivasi Kerja Guru Terhadap Kepuasan Kerja Guru di SMK ADB INVEST Se - Kota Surabaya". Jurnal Inspirasi Manajemen Pendidikan. Volume 4 No. 4 Hal $122-133$.

Rismawan, E. 2015.’Pengaruh Supervisi Kepala Sekolah Dan Motivasi Berprestasi Guru Terhadap Kinerja Mengajar Guru". Jurnal Administrasi Pendidikan. Volume 12 No. 1 Hal 114 -130.

Sahertian, A, P. 2000. Konsep Dasar dan Teknik Supervisi Pendidikan Dalam Rangka Pengembangan Sumber Daya Manusia. Jakarta: Rineka Cipta. Sahertian, A, P. 2000. Profil Pendidikan Profesional. Yogyakarta: Andi Offset.

Saondi,O. 2010. Etika Profesi Keguruan. Bandung: PT. Refika Aditama

Sugiyono. 2011. Metode Penelitian Administrasi. Bandung:Alfabeta.

Sumiata,N,G.2010. "Hubungan antara Kemampuan Manajerial Kepala Sekolah Supervisi Pembelajaran dan Iklim Organisasi Dengan Kinerja Guru SD NEGERI di Kecamatan Busungbiu Kabupaten Bulelleng".Jurnal administrasi Pendidikan Indonesia. Volume 1 No. 2 Hal 46 -67.

Tabi'in. 2017. "Supervisi Akademik Dalam Upaya Peningkatan Profesionalisme Guru PAI Madrasah Di KKMI Kecamatan Penjaringan”. Tesis. Jakarta: Sekolah Pascasarjana UIN. 
Uno, H, B. 2010. TEori Motivasi dan Pengukurannya; Analisis Di Bidang pendidikan. Jakarta; Bumi Aksara.

Undang - Undang Republik Indonesia Nomor 20 tahun 2003 Tentang Sistem Pendidikan Nasional

Undang - Undang Republik Indonesia Nomor 14 tahun 2005 Tentang Guru dan Dosen.

Wahjanta, Ei. 2007. "Pengaruh Supervisi Kunjungan Kelas Oleh Kepala Sekolah Dan Kompetensi Guru Terhadap Kinerja Guru Dan Prestasi Belajar Siswa SMA Negeri Se - Kota Magelang”. Tesis. Semarang: Sekolah Pascasarjana UNS.

Zepeda, J, S. 2006. "Cognitive Dissonance, Supervision, And Administrative Team Conflict". International Journal Of Educational Management. Volume 20 No. 3 Page $224-232$. 